\title{
An Efficient Synthesis of Novel 3-[(Heteroaryl-2-ylimino)- methyl]-4-hydroxy-chromen-2-ones and Analogue of Tetrazole Derivatives and Their Antibacterial Activity
}

\author{
Ramiz Hoti ${ }^{1}$, Hamit Ismaili ${ }^{1, *}$, Veprim Thaçi ${ }^{1, * \mathbb{C}}$, Gjyle Mulliqi-Osmani ${ }^{2}$, Malësore Pllana-Zeqiri ${ }^{1}$ \\ and Agon Bytyqi ${ }^{1}$ \\ 1 Department of Chemistry, Faculty of Mathematical and Natural Sciences, University of Prishtina \\ "Hasan Prishtina", 10000 Prishtina, Kosovo; ramiz.hoti@uni-pr.edu (R.H.); malsore_p@hotmail.com (M.P.-Z.); \\ goni_871@hotmail.com (A.B.) \\ 2 Faculty of Medicine, National Institute of Public Health of Kosovo, 10000 Prishtina, Kosovo; \\ mikrobiologiia@gmail.com \\ * Correspondence: hamit.ismaili@uni-pr.edu (H.I.); veprim.thaci@uni-pr.edu (V.T.)
}

check for updates

Citation: Hoti, R.; Ismaili, H.; Thaçi, V.; Mulliqi-Osmani, G.; Pllana-Zeqiri, M.; Bytyqi, A. An Efficient Synthesis of Novel 3-[(Heteroaryl-2-ylimino)methyl]-4-hydroxy-chromen-2-ones and Analogue of Tetrazole Derivatives and Their Antibacterial Activity. Molbank 2021, 2021, M1303. https://doi.org/10.3390/M1303

Academic Editor: Hideto Miyabe

Received: 28 October 2021

Accepted: 27 November 2021

Published: 2 December 2021

Publisher's Note: MDPI stays neutral with regard to jurisdictional claims in published maps and institutional affiliations.

Copyright: (c) 2021 by the authors. Licensee MDPI, Basel, Switzerland. This article is an open access article distributed under the terms and conditions of the Creative Commons Attribution (CC BY) license (https:/ / creativecommons.org/licenses/by/ $4.0 /)$.

\begin{abstract}
Synthesis of a series of the substituted [(pyridinyl and pyrimidin-2-ylimino)-ethyl]-4hydroxy-chromen-2-ones and their tetrazole derivates is presented in this study. By catalytic condensation of 4-hydroxy-3-acetylcoumarine 2 and 2-aminopyridines 3(a-d), 3-[(pyridin-2-ylimino)ethyl]-4-hydroxy-chromen-2-ones $4(\mathbf{a}-\mathbf{d})$ are synthesized in high yield. During the condensation reaction of 2 and 4-amino-2,6-dihydroxypyrimidine 3e, 3-[1-(2,6-Dihydroxy-pyrimidin-4-ylimino)ethyl]-4-hydroxy-chromen-2-one $4 \mathbf{e}$ as condensation products is synthesized. In following series, by cyclization reactions of compounds 4 (a-e) with sodium azide, analogue 3-substituted pyridin-2-yl and pyrimidin-2-yl-5-methyl-2,5-dihydro-1H-tetrazol-5-yl]-4-hydroxy-chromen-2-one 5(a-e) are synthesized the products. Structural characterization of the synthesized products is done on the basis of spectrometric data. Antibacterial activity of the compounds 4(a-e) and 5(a-e) against S. aureus, E. coli and Klebsiella was examined by measuring the inhibition zones around the disks marked with the corresponding products solution. The impact of substitutions in antimicrobial is also explored. Compounds with polar groups have shown significant antibacterial activity against these microorganisms.
\end{abstract}

Keywords: 4-hydroxy-chromen-2-one; condensation; cyclization; antibacterial; zones of inhibition

\section{Introduction}

Coumarin (2H-Chromen-2-one) derivatives are a large class of oxygen-containing heterocyclic compounds with particular importance. Many coumarins are found as ingredients of the plant world [1]. Most of them play an important role in various life processes. Some coumarins are involved in various enzymatic reactions because their benzopyran-2-one structure enables them to interact with diversity of enzymes in organisms, thereby exhibiting wide potentiality as bioactive drugs [2]. Coumarin derivatives first were known as important agents for the treatment and prevention of various diseases [3]. Some naturally occurring coumarins such as novobiocin, chlorobiocin and coumermycin are an unprecedented class of antibiotics, showing expressed activity against Gram-positive bacteria [4]. Many of the compounds being in this class exhibit various biological activities, such as antimicrobial [5,6], antifungal [7,8] and antimalarial [9]. It was reported that some coumarin analogues also exhibited antioxidant $[10,11]$, cytotoxic $[12,13]$ and anti-tubercular activity [14]. A significant number of substituted coumarins also show sedative, analgesic, anticoagulant [15], anti-HIV [16,17], antidiabetic [18] and hepatoprotective activity [19]. The dynamics of the anticoagulant action of warfarin in the human body has also been investigated. Several warfarin analogues are currently used as rodenticides [20]. Some synthesized chromen-2-ones reported as anticancer agents [21,22]. For this reason, many 
of coumarin derivatives have found widespread usage in pharmacies. On the other hand, tetrazoles and their heterocyclic analogues are useful drugs with a wide range of applications in medicine, agriculture and material sciences. Many tetrazoles are reported as important pharmacophores that demonstrate a wide range of pharmacological activities and are widely used in medicinal chemistry. Some tetrazole analogues as transporter inhibitors also are reported [23]. Many of them are reported to exhibit antihypertensive [24], anti-analgesic [25], anti-ulcer and anti-inflammatory activity [26]. The extraordinary biological importance of such derivatives on the basis of chromen-2-one has generated a constant interest in their synthesis and research. The biological activity of coumarin derivatives is conditioned by their structure. The type and potency of biological activity are conditioned by the presence of various substituents in the benzopyronic moiety. However, despite continuous efforts, the structure and biological activity relationship of these derivatives so far has not yet been sufficiently clarified. We have previously reported on the synthesis and antibacterial activity of some substituted chromen-2-one derivatives [27-29]. In continuation of our previous studies, in this paper our aim is to report about the synthesis of some new substituted 4-hydroxy-chromene-2-one derivatives through condensation reactions of 4-hydroxy-3-acetylcoumarin with substituted aminopyridines and aminopyrimidines, as well as some tetrazole analogues through cyclization reactions of these derivatives with sodium azide, for which so far there are no data from the literature. Following this work, their antibacterial activity against S. aureus, E. coli and Klebsiella also are screened. Based on the obtained results, we think that these compounds could find use as pharmaceutical products.

\section{Results and Discussion}

\subsection{Chemistry}

The 3-acetyl-4-hydroxycoumarin is synthesized by direct acetylation of 4-hydroxycouma rin with acetic acid in the presence of Phosphorous oxychloride as a catalyst, according to the procedure described in the literature [30]. By condensation reaction3-acety 4 hydroxycoumarin 2 and 2-amino-5-chloropyridine 3a, 3-[1-(5-Chloro-pyridin-2-ylimino)-ethyl]-4hydroxy-chromen-2-one 4a is synthesized. Condensation reaction of compound 2 and 2-amino3,5-dichloropyridine $3 \mathbf{b}$ resulted in formation of 3-[1-(3,5-Dichloro-pyridin-2-ylimino)-ethyl]-4hydroxy-chromen-2-one $\mathbf{4 b}$, whereas by condensation of 2 and 2-amino-5-bromopyridine $3 \mathbf{c}$ afforded 3-[1-(5-Bromo-pyridin-2-yl)-methyl]-4-hydroxy-chromen-2-one 4c. Reaction of 2 and 2-amino-3-benzyloxypyridine 3d gave 3-[1-(3-Benzyloxy-pyridin-2-ylimino)-ethyl]-4-hydroxychromen-2-one $4 \mathrm{~d}$, whereas condensation of 2 and 4-amino-2-6-dihydroxypyrimidine $3 \mathbf{e}$ afforded 3-[1-(2,6-Dihydroxy-pyrimidin-4-ylimino)-ethyl]-4-hydroxy-chromen-2-one 4e. In the last series of reactions, by cyclization of the product 4(a-e) with sodium azide, respective tetrazolyl analogues, 3-[1-(5-Chloro-pyridin-2-yl)-5-methyl-2,5-dihydro-1H-tetrazol-5-yl]-4hydroxy-chromen-2-one 5a, 3-[1-(3,5-Dichloro-pyridin-2-yl)-5-methyl-2,5-dihydro-1H-tetrazol-5yl]-4-hydroxy-chromen-2-one 5b, 3-[1-(5-Bromo-pyridin-2-yl)-5-methyl-2,5-dihydro-1H-tetrazol-5yl]-4-hydroxy-chromen-2-one 5c, 3-[1-(3-Benzyloxy-pyridin-2-yl)-5-methyl-2,5-dihydro-1H-tetrazo l-5-yl]-4-hydroxy-chromen-2-one 5d and 3-[1-(2,6-dihydroxy-pyrimidin-4-yl)-5-methyl-2,5-dihydr o-1H-tetrazol-5-yl]-4-hydroxychromen-2-one 5e are synthesized (Scheme 1).

The synthesized products $4(\mathrm{a}-\mathrm{e})$ and $\mathbf{5 ( a - e )}$ are characterized on the basis of spectrometric data and their elemental analysis. In the IR spectrum of the product $4 \mathrm{a}$ a broad absorption mode at $3450-3100 \mathrm{~cm}^{-1}$ appeared due to $v(\mathrm{OH})$ str. Vibrations, while an absorption signal at $3071.08 \mathrm{~cm}^{-1}$ resulted from aromatic $v(\mathrm{CH})$ str. vibrations. The absorption peaks appeared at $1730.57,1669.25$ and $1612.46 \mathrm{~cm}^{-1}$ due to stretching $v(C=O), v(C=N)$ and $v(C=C)$ of aromatic system, while the sharp peak at $765.33 \mathrm{~cm}^{-1}$ is due to aromatic $\delta(\mathrm{C}-\mathrm{H})$ oop. vibrations. 


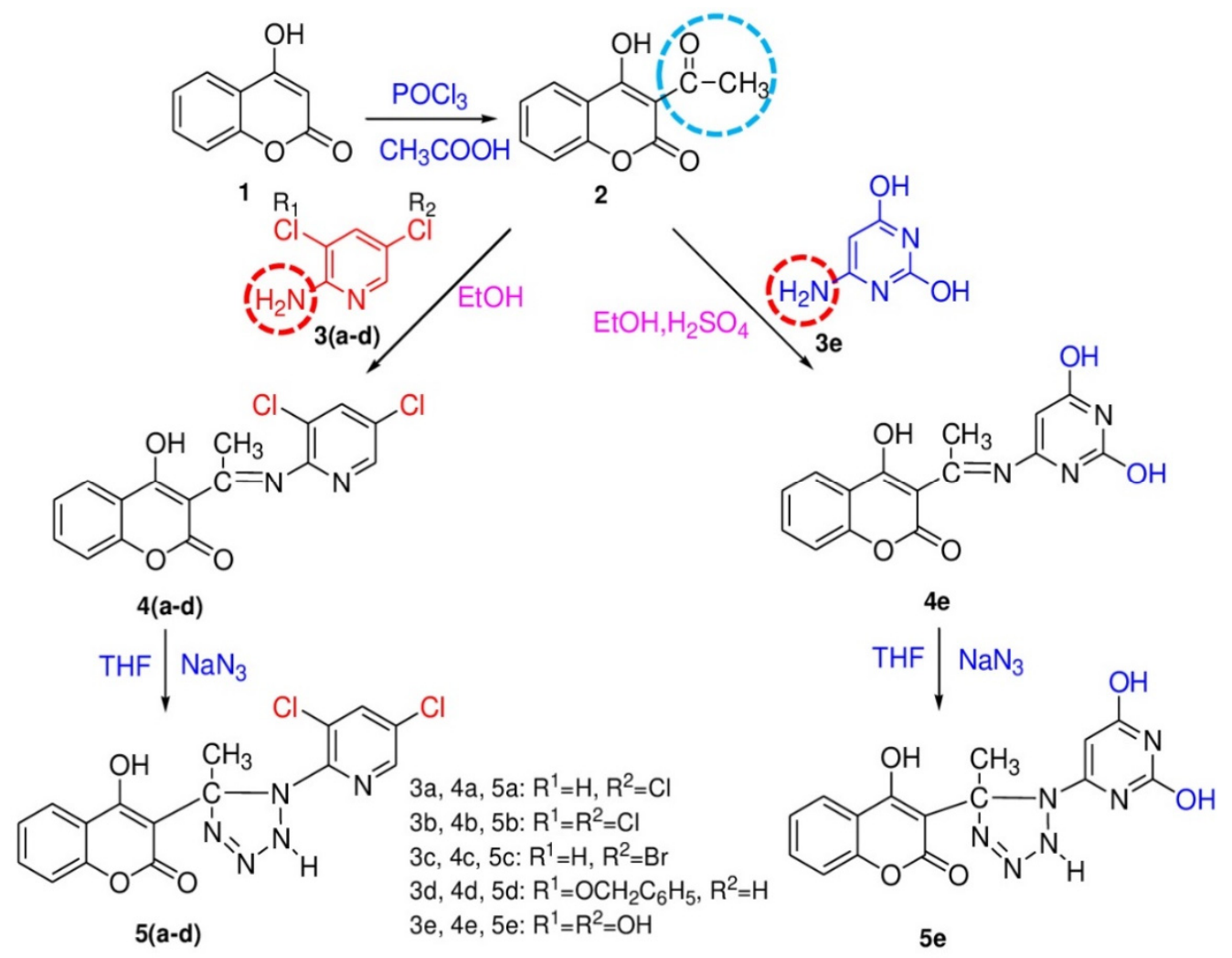

Scheme 1. Synthetic procedure to obtain the analogs of tetrazole derivatives.

In the ${ }^{1} \mathrm{H}$-NMR spectrum, except characteristic peaks of aromatic protons, a singlet at $8.10 \mathrm{ppm}$ and a doublet at $8.05 \mathrm{ppm}$ appeared due to protons of pyridine moiety, whereas a singlet at $0.95 \mathrm{ppm}$ resulted from methyl protons. The ${ }^{13} \mathrm{C}$-NMR spectrum showed characteristic absorptions for 16 carbon atoms. On the other hand, elemental analysis supports the structure of compound $4 \mathbf{a}$.

In the IR spectrum of $4 \mathrm{~b}$, the broad absorption band at $3440-3100 \mathrm{~cm}^{-1}$ resulted due to $v(\mathrm{OH})$ stretching vibrations. The signal appeared at $3053.62 \mathrm{~cm}^{-1}$ corresponding to $v(\mathrm{CH})$ str. of the aromatic ring, while the sharp peak at $1734.85 \mathrm{~cm}^{-1}$ is characteristic for $v(C=O)$ str. vibrations. Absorption modes at 1651.02 and $1610.45 \mathrm{~cm}^{-1}$ appeared due to $v(\mathrm{C}=\mathrm{N})$ str. and $v(\mathrm{C}=\mathrm{C})$ str. of the aromatic system. The mode at $1093.23 \mathrm{~cm}^{-1}$ is also characteristic for stretching $v(\mathrm{C}-\mathrm{O}-\mathrm{C})$ vibrations of the lactonic moiety, while absorptions at 867.28 and $756.94 \mathrm{~cm}^{-1}$ appeared due to $v(\mathrm{C}-\mathrm{Cl})$ str. and aromatic $\delta(\mathrm{C}-\mathrm{H})$ oop. vibrations. On the other hand, except for characteristic signals for aromatic protons, a singlet at $1.1 \mathrm{ppm}$ appeared due to methyl protons. ${ }^{13} \mathrm{C}-\mathrm{NMR}$ spectrum also showed characteristic peaks for 16 carbon atoms and the elemental analysis is consistent with the composition of this compound.

In the IR spectrum of the compound $4 \mathrm{~d}$ a broad absorption due to $v(\mathrm{OH})$ str. vibrations appeared at 3450-3100 $\mathrm{cm}^{-1}$ and peaks at 3067.46 and $2955.92 \mathrm{~cm}^{-1}$ are responsible for aromatic $v(\mathrm{CH})$ str. and methylene $v(\mathrm{CH})$ str. vibrations. The absorption modes at 1713.71 , 1662.02 and $1610.56 \mathrm{~cm}^{-1}$ resulted from lactonic $v(C=O)$ str., $v(C=N)$ str. and $v(C=C)$ str. vibrations of this compound. A signal at $1043.07 \mathrm{~cm}^{-1}$ and another at $756.72 \mathrm{~cm}^{-1}$ are responsible for lactonic $v(\mathrm{C}-\mathrm{O}-\mathrm{C})$ str. and aromatic $\delta(\mathrm{C}-\mathrm{H})$ oop. The ${ }^{1} \mathrm{H}-\mathrm{NMR}$ spectrum of $4 \mathrm{~d}$ showed aromatic protons appearing at $7.42 \mathrm{ppm}$ as a triplet, at $6.99 \mathrm{ppm}$ as a doublet and at $6.54 \mathrm{ppm}$ as a doublet of a doublet. A proton singlet resulting from methyl protons appeared at $1.2 \mathrm{ppm}$. In the ${ }^{13} \mathrm{C}-\mathrm{NMR}$ spectrum, methylene carbon appeared a signal at $75.2 \mathrm{ppm}$, whereas the elemental composition of product $4 \mathrm{~d}$ is confirmed by elemental analysis. 
IR spectrum of 4e showed a broad band at $3360-3000 \mathrm{~cm}^{-1}$ which is responsible for $v(\mathrm{OH})$ str. vibrations. Signals at $1725.67,1655.24$ and $1584.73 \mathrm{~cm}^{-1}$ resulted from the $v(\mathrm{C}=\mathrm{O})$ str., $v(\mathrm{C}=\mathrm{N})$ str. and $v(\mathrm{C}=\mathrm{C})$ str. vibrations, whereas characteristic modes at 1051.84 and $763.31 \mathrm{~cm}^{-1}$ appeared due to lactonic $v(\mathrm{C}-\mathrm{O}-\mathrm{C})$ str. and bending $\delta(\mathrm{CH})$ oop. vibrations of the aromatic ring. The ${ }^{1} \mathrm{H}-\mathrm{NMR}$ spectrum of $4 \mathrm{e}$, except doublets and doublet of doublets for aromatic protons, a singlet at $6.1 \mathrm{ppm}$ for pyrimidine proton has appeared. The ${ }^{13} \mathrm{C}-$ NMR spectrum of 4e showed characteristic signals for $\mathrm{C}-\mathrm{OH}$ carbons appeared at 175.2 and $174.7 \mathrm{ppm}$, while $\mathrm{C}=\mathrm{N}$ and $\mathrm{C}=\mathrm{O}$ carbons displayed corresponding absorptions 167.4 and $160.5 \mathrm{ppm}$, respectively. Elemental analysis of this compound also confirmed their composition. Tetrazoles 5(a-e) also are characterized on the basis of spectrometric data.

In the IR spectrum of compound 5a, except others, the absorption peak at 3420.34 and $1669.84 \mathrm{~cm}^{-1}$ resulted from $v(\mathrm{NH})$ str. and $v(\mathrm{~N}=\mathrm{N})$ str. argue the presence of tetrazole ring. The ${ }^{1} \mathrm{H}-\mathrm{NMR}$ spectrum of 5 a showed singlets at $8.2 \mathrm{ppm}$ of $\mathrm{N}=\mathrm{C}-\mathrm{H}$, at $3.2 \mathrm{ppm}$ of $\mathrm{N}-\mathrm{H}$ and another singlet at $1.3 \mathrm{ppm}$ of methyl protons. The ${ }^{13} \mathrm{C}-\mathrm{NMR}$ spectrum shows for 16 carbons, among which the characteristic ones are at $161.7 \mathrm{ppm}$ from $\mathrm{C}-\mathrm{N}$ of pyridine, a signal at $78.9 \mathrm{ppm}$ from C-tetrazole, and the other signal at $20.2 \mathrm{ppm}$ due to methyl carbon.

In the IR spectrum of product $\mathbf{5 b}$ the characteristic signals appeared at 3391.65 and $1680.35 \mathrm{~cm}^{-1}$, which resulted from $\mathrm{v}(\mathrm{NH})$ and $\mathrm{v}(\mathrm{N}=\mathrm{N})$ str. vibrations of the tetrazole ring, respectively. Tetrazole residue was also confirmed by the presence of a singlet at $3.5 \mathrm{ppm}$ from tetrazole. Another singlet at $1.4 \mathrm{ppm}$ resulted from methyl protons. Tetrazole moiety also is confirmed from characteristic modes at $76.8 \mathrm{ppm}$ in the ${ }^{13} \mathrm{C}-\mathrm{NMR}$ spectrum, whereas absorption mode at 21,5 ppm resulted from methyl carbon.

Compound $5 \mathrm{c}$ exhibited absorption mode from vibrations $v(\mathrm{~N}=\mathrm{N})$ str. at $1650.31 \mathrm{~cm}^{-1}$, while in the ${ }^{1} \mathrm{H}-\mathrm{NMR}$ spectrum the singlets at $2.1 \mathrm{ppm}$ and at $1.4 \mathrm{ppm}$ appeared resulting from tetrazole and methyl protons. The ${ }^{13} \mathrm{C}-\mathrm{NMR}$ spectrum showed the characteristic signal for C-tetrazole at $76.1 \mathrm{ppm}$, as well as the characteristic signals for 15 other aromatic carbons.

In the IR spectrum of the $\mathbf{5 d}$ compound, except aromatic $v(\mathrm{CH})$ str. vibrations at $3079.55 \mathrm{~cm}^{-1}$, the $v(\mathrm{CH})$ str. mode of the methyl group at $2947.48 \mathrm{~cm}^{-1}$ are also observed, while a signal displayed at $1665.82 \mathrm{~cm}^{-1}$ resulted from $v(\mathrm{~N}=\mathrm{N})$ str. vibrations. The ${ }^{1} \mathrm{H}-$ NMR spectrum shows the corresponding a signal at $2.2 \mathrm{ppm}$ of the tetrazole proton, as well as a singlet at $1.4 \mathrm{ppm}$ from the $\mathrm{CH}_{3}$ protons. Absorption mode at $78.8 \mathrm{ppm}$ in the ${ }^{13} \mathrm{C}$-NMR spectrum argues the presence of tetrazole moiety.

A broad band in the IR spectrum of 5e displayed at $3420-3100 \mathrm{~cm}^{-1}$ has resulted from $v(\mathrm{OH})$ str. vibrations, while the peak at 3450.05 appeared due to $v(\mathrm{NH})$ str. vibrations. On the other hand, absorption mode at $1665.82 \mathrm{~cm}^{-1}$ reflects the $v(\mathrm{~N}=\mathrm{N})$ str. vibrations of the tetrazole ring. In support of confirmation of tetrazole ring is also the singlet displayed at $2.2 \mathrm{ppm}$ in the ${ }^{1} \mathrm{H}$-NMR spectrum, as well as the signal at $78.8 \mathrm{ppm}$ in the ${ }^{13} \mathrm{C}-\mathrm{NMR}$ spectrum. The structure of compounds $5(\mathrm{a}-\mathrm{e})$ has also been confirmed by its elementary analysis (Table 1).

Table 1. Physical properties of compounds 4(a-e) and 5(a-e) and their elemental analysis.

\begin{tabular}{|c|c|c|c|c|c|}
\hline $\mathrm{Nr}$ & $\begin{array}{l}\text { Molecular } \\
\text { Formulas }\end{array}$ & $\begin{array}{l}\text { Molecular } \\
\text { Mass }\end{array}$ & $\begin{array}{l}\text { Elemental Analysis \% } \\
\text { Calc/Found }\end{array}$ & $\mathrm{mp} /{ }^{\circ} \mathrm{C}$ & Yield \% \\
\hline $4 a$ & $\mathrm{C}_{16} \mathrm{H}_{11} \mathrm{~N}_{2} \mathrm{O}_{3} \mathrm{Cl}$ & 314.71 & $\begin{array}{c}\text { (C-61.06; H-3.52; N-8.90; O-15.25; Cl-11.26) } \\
\text { (C-61.02; H-3.51; N-8.85; Cl: 11.28) }\end{array}$ & 204-206 & 66 \\
\hline $4 b$ & $\mathrm{C}_{16} \mathrm{H}_{10} \mathrm{~N}_{2} \mathrm{O}_{3} \mathrm{Cl}_{2}$ & 349.15 & $\begin{array}{c}\text { (C-55.03; H-2.89; N-8.02; O-13.75; Cl-20.31) } \\
\quad(\mathrm{C}-49.99 ; \mathrm{H}-2.86 ; \mathrm{N}-8.04 ; \mathrm{Cl}-20.27)\end{array}$ & $212-214$ & 72 \\
\hline $4 c$ & $\mathrm{C}_{16} \mathrm{H}_{11} \mathrm{~N}_{2} \mathrm{O}_{3} \mathrm{Br}$ & 359.16 & $\begin{array}{c}\text { (C-53.50; H-3.09; N-7.80; O-13.36; Br-22.25) } \\
\text { (C-53.48; H-3.12; N-7.76; Br-22.21) }\end{array}$ & $225-227$ & 75 \\
\hline $4 d$ & $\mathrm{C}_{23} \mathrm{H}_{18} \mathrm{~N}_{2} \mathrm{O}_{4}$ & 385.38 & $\begin{array}{l}\text { (C-71.68; H-4.70; N-7.27; O-16.60) } \\
\text { (C-71.72; H-4.67; N-7.24) }\end{array}$ & 305-307 & 38 \\
\hline
\end{tabular}


Table 1. Cont.

\begin{tabular}{cccccc}
\hline $\mathbf{N r}$ & $\begin{array}{c}\text { Molecular } \\
\text { Formulas }\end{array}$ & $\begin{array}{c}\text { Molecular } \\
\text { Mass }\end{array}$ & $\begin{array}{c}\text { Elemental Analysis \% } \\
\text { Calc/Found }\end{array}$ & mp/ ${ }^{\circ} \mathbf{C}$ & Yield \% \\
\hline $\mathbf{4 e}$ & $\mathrm{C}_{15} \mathrm{H}_{11} \mathrm{~N}_{3} \mathrm{O}_{5}$ & 313.26 & $\begin{array}{c}(\mathrm{C}-57.51 ; \mathrm{H}-3.54 ; \mathrm{N}-13.41 ; \mathrm{O}-25.54) \\
(\mathrm{C}-57.47 ; \mathrm{H}-3.56 ; \mathrm{N}-13.38)\end{array}$ & $302-304$ & 62 \\
$\mathbf{5 a}$ & $\mathrm{C}_{16} \mathrm{H}_{12} \mathrm{~N}_{5} \mathrm{O}_{3} \mathrm{Cl}$ & 357.74 & $\begin{array}{c}(\mathrm{C}-53.71 ; \mathrm{H}-3.38 ; \mathrm{N}-19.57 ; \mathrm{O}-13.42 ; \mathrm{Cl}-9.91) \\
(\mathrm{C}-53.66 ; \mathrm{H}-3.42 ; \mathrm{N}-19.60 ; \mathrm{Cl}-9.87)\end{array}$ & $211-213$ & 65 \\
$\mathbf{5 b}$ & $\mathrm{C}_{16} \mathrm{H}_{11} \mathrm{~N}_{5} \mathrm{O}_{3} \mathrm{Cl} \mathrm{C}_{2}$ & 392.18 & $\begin{array}{c}(\mathrm{C}-48.99 ; \mathrm{H}-2.83 ; \mathrm{N}-17.86 ; \mathrm{O}-12.24 ; \mathrm{Cl}-18.08) \\
(\mathrm{C}-49.03 ; \mathrm{H}-2.79 ; \mathrm{N}-17.84 ; \mathrm{Cl}-18.03)\end{array}$ & $208-211$ & 73 \\
$\mathbf{5} \mathbf{c}$ & $\mathrm{C}_{16} \mathrm{H}_{12} \mathrm{~N}_{5} \mathrm{O}_{3} \mathrm{Br}$ & 402.19 & $\begin{array}{c}(\mathrm{C}-47.78 ; \mathrm{H}-3.01 ; \mathrm{N}-17.41 ; \mathrm{O}-11.93 ; \mathrm{Br}-19.87) \\
(\mathrm{C}-47.82 ; \mathrm{H}-2.98 ; \mathrm{N}-17.38 ; \mathrm{Br}-19.90)\end{array}$ & $120-122$ & 70 \\
$\mathbf{5 d}$ & $\mathrm{C}_{23} \mathrm{H}_{19} \mathrm{~N}_{5} \mathrm{O}_{4}$ & 429.41 & $\begin{array}{c}(\mathrm{C}-64.33 ; \mathrm{H}-4.46 ; \mathrm{N}-16.31 ; \mathrm{O}-14.19) \\
(\mathrm{C}-64.29 ; \mathrm{H}-4.44 ; \mathrm{N}-16.28)\end{array}$ & $224-226$ & 67 \\
$\mathbf{5 e}$ & $\mathrm{C}_{15} \mathrm{H}_{12} \mathrm{~N}_{6} \mathrm{O}_{5}$ & 356.29 & $(\mathrm{C}-50.56 ; \mathrm{H}-3.39 ; \mathrm{N}-23.59 ; \mathrm{O}-22.45)$ & $223-225$ & 45 \\
$(\mathrm{C}-50.58 ; \mathrm{H}-3.43 ; \mathrm{N}-23.62)$ & & & & \\
\hline
\end{tabular}

\subsection{Antibacterial Activity of the Products 4(a-e) and 5(a-e)}

In the following, this study includes results of antibacterial activity of products 4 (a-e) and 5(a-e). Our research has focused on testing the antibacterial activity of these compounds against the bacteria S. aureus, E. coli and Klebsiella. Screening of antibacterial activity was done on the basis of Kirby Bayer method [30-32], by measuring the zones of inhibition around the standard discs that have previously been marked with solutions of the products in N,N-DMF with concentrations of $2 \mathrm{mg} / \mathrm{mL}, 4 \mathrm{mg} / \mathrm{mL}$ and $6 \mathrm{mg} / \mathrm{mL}$. The bacterial cultures have incubated for $48 \mathrm{~h}$ at $37^{\circ} \mathrm{C}$. The biological evaluation also is based on previous studies $[33,34]$.

The results in Figures 1-3 show that compounds of series 4 and 5 showed exhibited considerable activity against these bacteria. Compounds $4 \mathbf{b}$ and $5 \mathbf{e}$ expressed the significant activity against $S$. aureus, while $5 \mathbf{b}$ and $4 \mathbf{e}$ were most active against $E$. coli, and $5 \mathbf{b}$ and 5e were more active against Klebsiella. These compounds expressed both bactericide and bacteriostatic activity against $S$. aureus. Furthermore, antibacterial activity against $E$. coli and Klebsiella is displayed on a large-scale as bactericide activity. In general, the bacteriostatic activity is exhibited in a large range $(+4 \mathrm{~mm})$, whereas bactericide activity showed in small diameter. The influence of polar groups was quite pronounced. while tetrazole moiety appeared low impact on antimicrobial activity. The impact of chlorine is particularly noted which has affected the increase of antibacterial activity. The pyrimidine hydroxyl groups 5e has shown a significant impact on the range of antibacterial activity against the bacterial culture Klebsiella. Based on these results we consider that antibacterial activity may result as a consequence of the involvement of these compounds in enzymatic reactions during bacterial reproduction. It is believed that these compounds may have caused enzymatic inhibition by binding to the active center of enzymes that participates in the cellular wall construction of these bacteria. However, the mechanism of inhibition is not yet fully studied. In general, antimicrobial activity increased by increasing the concentration of the products. 


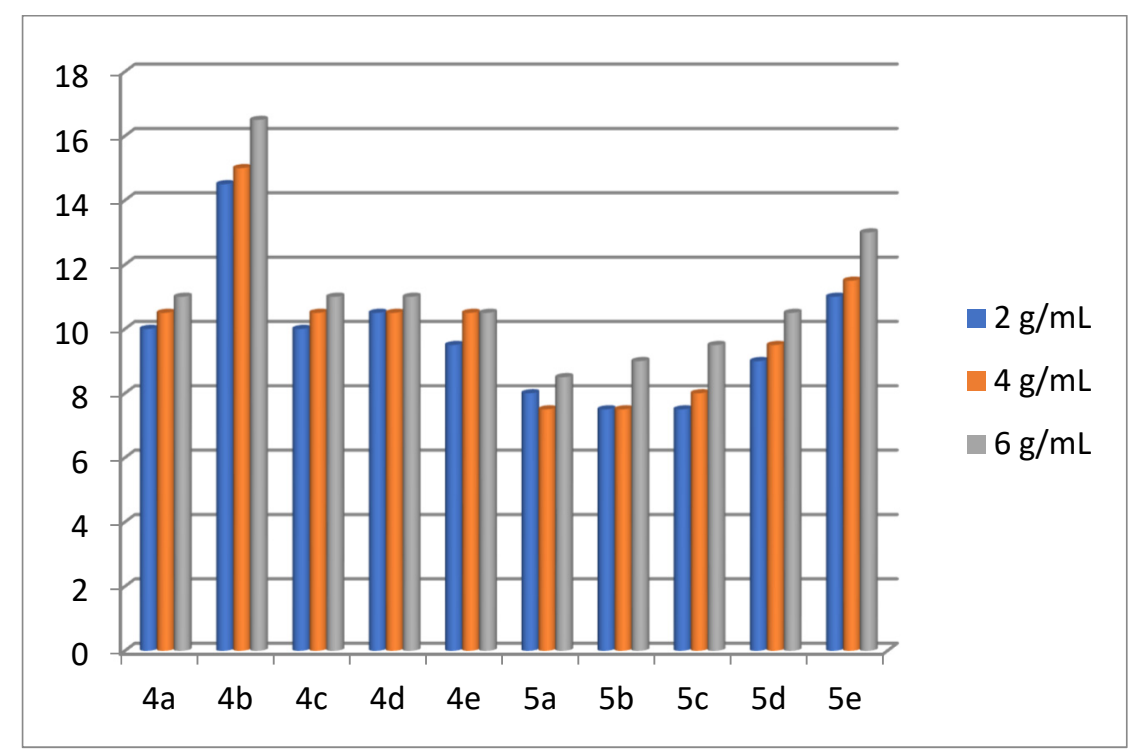

Figure 1. Graphical presentation of inhibition zone diameter ( $\mathrm{mm}$ ) against S. aureus.

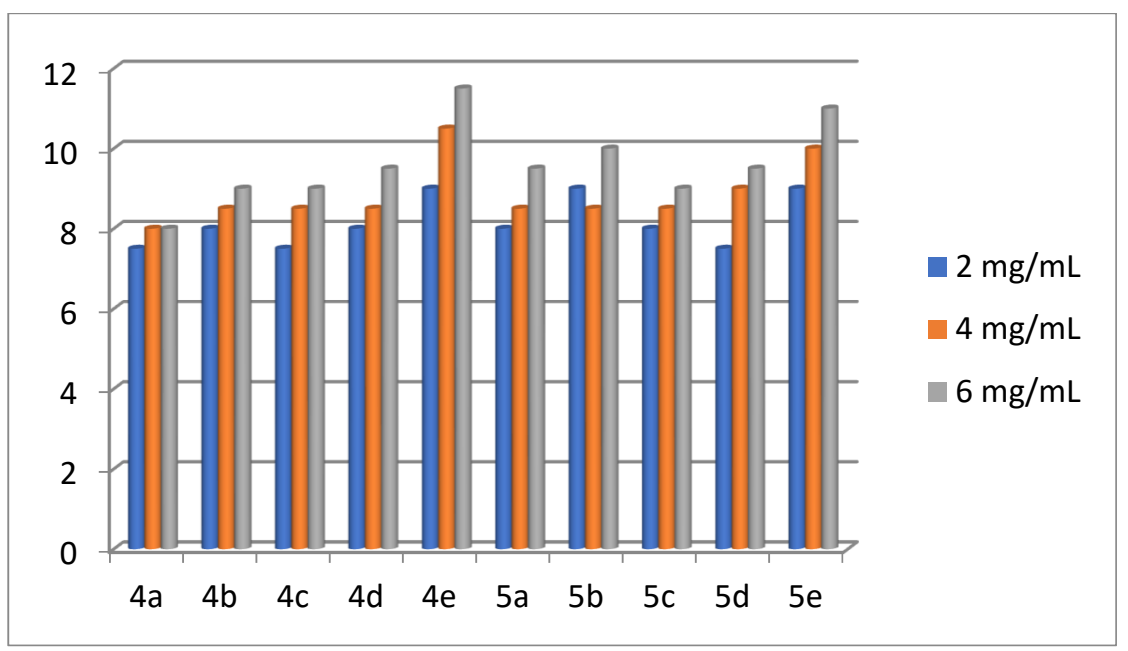

Figure 2. Graphical presentation of inhibition zone diameter (mm) against E. coli.

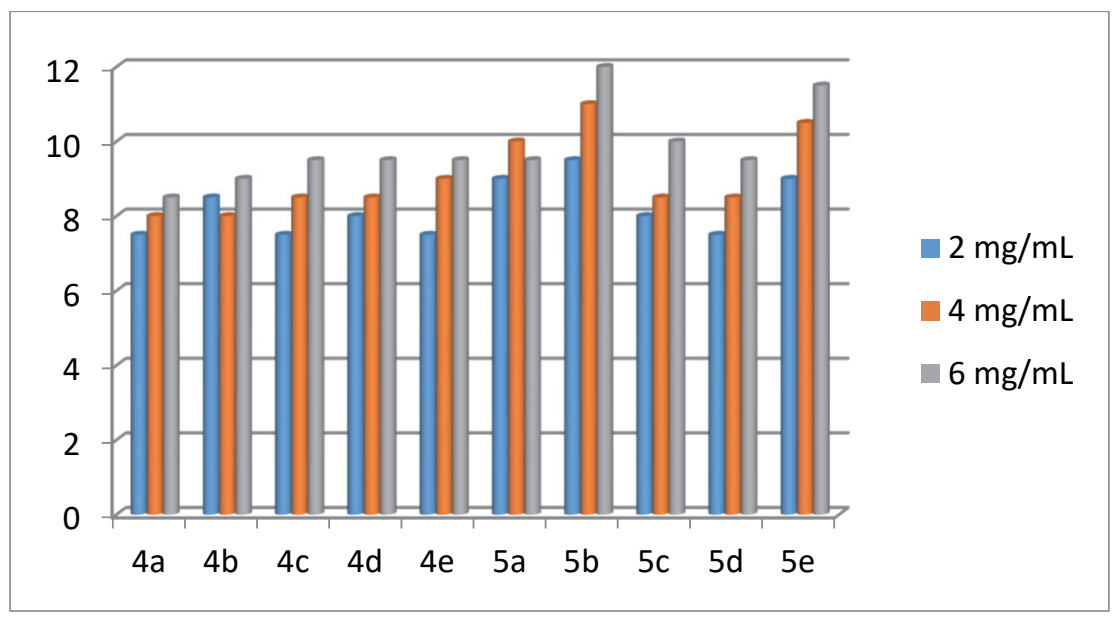

Figure 3. Graphical presentation of inhibition zone diameter ( $\mathrm{mm}$ ) against Klebsiella. 


\section{Material and Methods}

\subsection{Materials and Basic Measurements}

The new compounds are synthesized under refluxing conditions using commercial reagents of Aldrich company as precursors with pro-analysis purity. Reaction flow was monitored by TLC using Merck Kieselgel-60 (F-254) as the stationary phase and mixture of benzene, toluene, glacial acetic acid $(v / v / v, 80: 10: 10)$ as mobile phase, visualization with Uv lamp. Purification of the products is done by recrystallization from ethanol. Melting points of the compounds were determined in a paraffin oil bath with an open capillary tube and are uncorrected. IR spectra are recorded in KBr discs on Shimadzu 8400xFTIR spectrometer with $4 \mathrm{~cm}^{-1}$ resolution. ${ }^{1} \mathrm{H}-\mathrm{NMR}$ and ${ }^{13} \mathrm{C}-\mathrm{NMR}$ spectra are recorded in DMSO- $d_{6}$ on UNITYplus-500“NMR 1" spectrometer. Chemical shifts were reported in ppm down field from TMS as internal standard (80.00). Antibacterial activity of the compounds was examined on the basis of Kirby-Bayer's method, using standard discs $(\mathrm{d}=5.0 \mathrm{~mm}$, maximum capacity10 $\mathrm{pg})$. Standard discs are previously saturated with compound solutionsin N,N-DMF concentrations $2 \mathrm{mg} / \mathrm{mL}, 4 \mathrm{mg} / \mathrm{mL}$ and $6 \mathrm{mg} / \mathrm{mL}$.

\subsection{3-[Pyridin-2-ylimino)-ethyl]-4-hydroxy-chromen-2-ones 4(a-e), General Procedure}

3-Acetyl-4-hydroxycoumarin $2(0.82 \mathrm{~g}, 0.004 \mathrm{~mol})$ is dissolved in $15 \mathrm{~mL}$ ethanol and $2-3$ drops of sulphuric acid is added. The mixture is stirred at room temperature and an equimolar amount of corresponding 2-aminopyridine 3a-d or 4-aminopyrimidine $3 \mathbf{e}$ ( $0.004 \mathrm{~mol}$ dissolved in $10 \mathrm{~mL}$ ethanol) is added to the mixture in small portions, then the mixture is refluxed for 6-8 h. After cooling, the mixture is concentrated in the rotary evaporator, the residue is cooled and the crystalline product is filtered off under vacuum and washed with $2 \times 2 \mathrm{~mL}$ of ethanol. The crystalline product is dried and recrystallized from ethanol.

\subsection{3-[1-(5-Chloro-pyridin-2-ylimino)-ethyl]-4-hydroxy-chromen-2-one}

4a: $\mathrm{mp}=204-206{ }^{\circ} \mathrm{C}$ reflux time $6 \mathrm{~h}, \mathrm{R}=66 \%$. IR $\left(\mathrm{KBr}\right.$ disc, $\left.\mathrm{cm}^{-1}\right): 3450-3100,3071.08$, 1730.57, 1669.25, 1612.46, 1073.94, 765.33. ${ }^{1} \mathrm{H}-\mathrm{NMR}$; $(\delta, \mathrm{ppm}) 8.10(\mathrm{~s}, 1 \mathrm{H} \mathrm{Pyr}), 8.05(\mathrm{~d}, 1 \mathrm{H}$, Pyr), 7.76 (d, 1H, Ar), 7.64-7.61 (t, 1H, Ar), 7.40-7.36 (m, 2H, Ar), 7.12 -7.07 (t, 1H, Ar), 0.95 $\left(\mathrm{s}, 3 \mathrm{H}, \mathrm{CH}_{3}\right) .{ }^{13} \mathrm{C}-\mathrm{NMR} ;(\delta, \mathrm{ppm}) 170.6(\mathrm{C}-2, \mathrm{Pyr}),. 163.6(\mathrm{C}=\mathrm{N}), 163.2(\mathrm{C}=\mathrm{N}), 162.4(\mathrm{C}=\mathrm{O})$, 159,5 (C-OH), 151.4, 149.5, 134.6, 128.8, 128.2, 125,7, 125.2, 124.8, 123.6, 121.9, 11.6.

\subsection{3-[1-(3,5-Dichloro-pyridin-2-ylimino)-ethyl]-4-hydroxy-chromen-2-one}

4b: $\mathrm{mp}=212-214{ }^{\circ} \mathrm{C}$ reflux time $6 \mathrm{~h}, \mathrm{R}=72 \% . \mathrm{IR}\left(\mathrm{KBr}\right.$ disc, $\left.\mathrm{cm}^{-1}\right): 3440-3100,3053.62$, 1734.85, 1651.02, 1610.45, 1093.23, 867.28, 756.94. ${ }^{1} \mathrm{H}-\mathrm{NMR}$; $(\delta, \mathrm{ppm}), 8.7$ (s, $\left.1 \mathrm{H}, \mathrm{Pyr}\right), 8.1$ (s, 1H, Pyr), 7.5-7.3 (m, 2H, Ar), 7.2-7.0 (m, 2H, Ar), 1.1 (s, $\left.\mathrm{CH}_{3}\right) .{ }^{13} \mathrm{C}-\mathrm{NMR} ;(\delta, \mathrm{ppm}) 167.9$ (C-2 Pyr), $163.6(\mathrm{C}=\mathrm{N}), 160.8(\mathrm{C}=\mathrm{O}), 151.2,147.8,134.5,128.2,127,8,126,4,125.2,124.4$, 123.0, 121.5, 120.2, 111.3, 11.2.

\subsection{3-[1-(5-Bromo-pyridin-2-ylimino)-ethyl]-4-hydroxy-chromen-2-one}

4c: $\mathrm{mp}=125-127^{\circ} \mathrm{C}$ reflux time $7 \mathrm{~h}, \mathrm{R}=75 \%$. IR $\left(\mathrm{KBr}\right.$ disc, $\left.\mathrm{cm}^{-1}\right)$ : 3500-3110, 3068.35, 1739.44, 1683.37, 1022.41. ${ }^{1} \mathrm{H}-\mathrm{NMR}$; ( $\delta$, ppm), 8.75-8.8.73 (s, 1H Pyr), 8.18-8.14 (d, 1H, Pyr), 7.74-7.71 (t, 1H, Ar), 7.68-7.66 (d, 1H, Ar), 7.41-7.37 (m, 2H, Ar), 7.24 -7.21 (t, 1H, Ar), 1.20 (s, 3H, $\left.\mathrm{CH}_{3}\right)$. ${ }_{13} \mathrm{C}-\mathrm{NMR} ;(\delta, \mathrm{ppm}) 169.4(\mathrm{C}-2, \mathrm{Pyr}),. 164.2(\mathrm{C}=\mathrm{N}), 163.0(\mathrm{C}=\mathrm{N}), 161.2(\mathrm{C}=\mathrm{O})$, $152.5,150.1,149.3,137.0,129.6,128.2,126.7,125.3,124.1,123.5,120.8,10.8$.

\subsection{3-[1-(3-Benzyloxy-pyridin-2-ylimino)-ethyl]-4-hydroxy-chromen-2-one}

4d: $\mathrm{mp}=305-307^{\circ} \mathrm{C}$ reflux time $6 \mathrm{~h}, \mathrm{R}=38 \% . \mathrm{IR}\left(\mathrm{KBr}\right.$ disc, $\left.\mathrm{cm}^{-1}\right)$ : 3450-3100, 3067.46, 2955.92, 1713.71, 1662.02, 1610.56, 1043.07, 756.72. ${ }^{1} \mathrm{H}-\mathrm{NMR}$; $(\delta, \mathrm{ppm}), 8.3(\mathrm{~s}, 1 \mathrm{H}, \mathrm{N}=\mathrm{C}-\mathrm{H}$, Pyr.), 7.74-7.73 (d, 1H), 7.68-7.67 (d, 1H), 7.42-7.41 (t, 1H), 6.99-6.97 (d, 1H), 6.87-6.70 (m), 6.54-6.51 (dd, 1H), $5.06(\mathrm{~s}, 2 \mathrm{H}), 1.2\left(\mathrm{~s}, 3 \mathrm{H}, \mathrm{CH}_{3}\right) .{ }^{13} \mathrm{C}-\mathrm{NMR} ;(\delta, \mathrm{ppm}) 164.5(\mathrm{C}=\mathrm{N}), 161.8$ $(\mathrm{C}=\mathrm{O}), 156.6,151.2,150,5,146.7,139.5,129.8,128.2,127.6,127,1,126.7,126,2,125.9,125.3$, $123.4,122.5,121.6,120.3,110.6,75.2,\left(\mathrm{O}-\mathrm{CH}_{2}\right)$. 


\subsection{3-[1-(2,6-Dihydroxy-pyrimidin-4-ylimino)-ethyl]-chromen-2-one}

4e: $\mathrm{mp}=302-304{ }^{\circ} \mathrm{C}$ reflux time $8 \mathrm{~h}, \mathrm{R}=62 \%$. IR $\left(\mathrm{KBr}\right.$ disc, $\left.\mathrm{cm}^{-1}\right): 3360-3000,1725.67$, 1655.24, 1584.73, 1051.84, 763.31. ${ }^{1} \mathrm{H}-\mathrm{NMR}$; $(\delta, \mathrm{ppm}), 7.75$ (d, 1H, Ar), 7.54 (dd, 1H), 7.24 $(\mathrm{dd}, 1 \mathrm{H}), 7.18(\mathrm{~d}, 1 \mathrm{H}, \mathrm{Ar}), 6.1$ (s, 1H, Pyrim), $5.4(\mathrm{~s}, 2 \mathrm{H}), 1.12\left(\mathrm{~s}, 3 \mathrm{H}, \mathrm{CH}_{3}\right) .13 \mathrm{C}-\mathrm{NMR} ;(\delta$, ppm) 175.2 (C-OH), $174.7(\mathrm{C}-\mathrm{OH}), 167.4(\mathrm{C}-\mathrm{N}), 165.2,162.8,160.5(\mathrm{C}=\mathrm{O}), 148.6,149.6,129.7$, $128.5,126.5,125.9,121.6,92.6,12.4\left(\mathrm{CH}_{3}\right)$.

3.8. 3-[Pyridin-2-yl)-5-methyl-2,5-dihydro-1H-tetrazol-5-yl]-4-hydroxy-chromen-2-ones 5(a-e), general procedure

The mixture of compound 4(a-e) $(0.002 \mathrm{~mol})$ and $0.2 \mathrm{~g}(0.003 \mathrm{~mol})$ of sodium azide dissolved in $15 \mathrm{~mL}$ tetrahydrofuran refluxed for $6-8 \mathrm{~h}$. The mixture is cooled in an ice bath and concentrated, then the crystalline product is filtered off under reduced pressure, then washed with $2 \times 1 \mathrm{~mL}$ of ethanol and dried in the air. Compounds $5(\mathbf{a}-\mathbf{e})$ were purified by recrystallization from ethanol.

3.9. 3-[1-(5-Chloro-pyridin-2-yl)-5-methyl-2,5-dihydro-1H-tetrazol-5-yl]-4-hydroxy-chromen2-one

5a:mp $=211-213{ }^{\circ} \mathrm{C}, \mathrm{R}=65 \%$, IR $\left(\mathrm{KBr}\right.$ disc, $\left.\mathrm{cm}^{-1}\right): 3450-3100,3420.34,3051.48,2983.65$, 1708,77, 1669.84, 1612.27, 1603.57, 1082.38, 897.25, 758.84. ${ }^{1} \mathrm{H}-\mathrm{NMR} ;(\delta, \mathrm{ppm}), 8.2(\mathrm{~s}, 1 \mathrm{H}$, $\mathrm{N}=\mathrm{C}-\mathrm{H}), 7.6-7.4(\mathrm{~m}, 3 \mathrm{H}, \mathrm{Ar}), 7.3-7.2(\mathrm{~m}, 2 \mathrm{H}, \mathrm{Pyr}), 3.2\left(\mathrm{~s},{ }^{1} \mathrm{H}\right), 1.3\left(\mathrm{~s}, 3 \mathrm{H}, \mathrm{CH}_{3}\right) .{ }^{13} \mathrm{C}-\mathrm{NMR}$; ( $\delta$, ppm) 166.1 C-OH, 162.8(C=O), 161.7 (C-N, Pyr.), 151,4, 148.3, 145.7, 139,2, 129.2, 128.3, 127.2, 126.6, 122.5, 121.0, 95.2, 78.9 (C-Tetraz.), $20.2\left(\mathrm{CH}_{3}\right)$. Please see Figure S2.

3.10. 3-[1-(3,5-Dichloro-pyridin-2-yl)-5-methyl-2,5-dihydro-1H-tetrazol-5-yl]-4-hydroxychromen-2-one

5b: $\mathrm{mp}=208-211^{\circ} \mathrm{C}, \mathrm{R}=73 \%$, IR $\left(\mathrm{KBr}\right.$ disc, $\left.\mathrm{cm}^{-1}\right): 3420-3080,3391.65,3072.93$, 2982.75, 1708,68, 1680.35, 1624.59, 1607.2, 1054.64, 912.42, 760.36. ${ }^{1} \mathrm{H}-\mathrm{NMR} ;(\delta, \mathrm{ppm}), 8.2(\mathrm{~s}$, $1 \mathrm{H}, \mathrm{N}=\mathrm{C}-\mathrm{H}), 7.8(\mathrm{~s}, 1 \mathrm{H}), 7.5-7.2(\mathrm{~m}, 4 \mathrm{H}, \mathrm{Ar}), 3.5,1.4\left(\mathrm{~s}, 3 \mathrm{H}, \mathrm{CH}_{3}\right) .{ }^{13} \mathrm{C}-\mathrm{NMR} ;(\delta, \mathrm{ppm}) 163.9$ (C-OH), 161.2 (C=O), 157.4 (C-N, Pyr.), 149,8, 138,3, 129.5, 128.4, 127,3, 127.0, 126,3, 125.2, 123.7, 122.7, 108.4, 76.8 (C-Tetraz.), $21.5\left(\mathrm{CH}_{3}\right)$. Please see Figure S3.

\subsection{3-[1-(5-Bromo-pyridin-2-yl)-methyl-2,5-dihydro-1H-tetrazol-5-yl]-4-hydroxy-chromen-} 2-one

5c: $\mathrm{mp}=120-122{ }^{\circ} \mathrm{C}, \mathrm{R}=70 \%, \mathrm{IR}\left(\mathrm{KBr}\right.$ disc, $\left.\mathrm{cm}^{-1}\right)$ : 3450-3100, 3068.38, 2974.38, 1711,46, 1650.31, 1602.26, 1600.31, 1049.39, 796.82, 764.32. ${ }^{1} \mathrm{H}-\mathrm{NMR} ;(\delta, \mathrm{ppm}) 8.2(\mathrm{~s}, 1 \mathrm{H}$, $\mathrm{N}=\mathrm{C}-\mathrm{H}), 7.8(\mathrm{~d}, 1 \mathrm{H}), 7.5-7.7(\mathrm{~m}, 3 \mathrm{H}, \mathrm{Ar}), 7.1(\mathrm{~d}, 1 \mathrm{H}), 3.5(\mathrm{~s}, 1 \mathrm{H}) .1 .4(\mathrm{~s}, 3 \mathrm{H}),,{ }^{13} \mathrm{C}-\mathrm{NMR} ;(\delta$, ppm) 166.4 (C-OH), 162.1 (C=O), 160.5 (C-N, Pyr.), 148.8, 145.6, 137,8, 129.2, 128.6, 127,3, 127.0, 125,1, 122.7, 120.8, 109.6, 76.1 (C-Tetraz.), $21.3\left(\mathrm{CH}_{3}\right)$.

\subsection{3-[1-(3-Benzyloxy-pyridin-2-yl)-5-methyl-2,5-dihydro-1H-tetrazol-5-yl]-4-hydroxy-} chromen-2-one

5d: $\mathrm{mp}=224-226^{\circ} \mathrm{C}, \mathrm{R}=67 \%$, IR $\left(\mathrm{KBr}\right.$ disc, $\left.\mathrm{cm}^{-1}\right): 3420-3100,3055.28,2957.72$, 1711.34, 1694,32, 1616.38, 1233.86, 1120.1, 762.53. ${ }^{1} \mathrm{H}-\mathrm{NMR} ;(\delta, \mathrm{ppm}) 7.9(\mathrm{~d}, 1 \mathrm{H}), 7.5-7.8(\mathrm{~m}$, $4 \mathrm{H}, \mathrm{Ar}), 7.3-7.1(\mathrm{~m}, 5 \mathrm{H}), 7.0(\mathrm{~d}, 1 \mathrm{H}), 6.8(\mathrm{dd}, 1 \mathrm{H}), 5.4\left(\mathrm{~s}, 2 \mathrm{H}, \mathrm{OCH}_{2}\right), 3.4(\mathrm{~s}, 1 \mathrm{H}),, 1.4(\mathrm{~s}, 3 \mathrm{H}$, $\left.\mathrm{CH}_{3}\right) .{ }^{13} \mathrm{C}-\mathrm{NMR} ;(\delta, \mathrm{ppm}) 165.4(\mathrm{C}-\mathrm{OH}), 163.8(\mathrm{C}=\mathrm{O}), 152.4$ (C-N, Pyr.), 148.3, 144.8, 143.4, $131.5,130.4,129.3,128,7,127,6,127.0,126.5,126.0,125.6,124.2,122.7,122.2,120.8,109.6$, 96.5, 77.4 (C-Tetraz.), $19.8\left(\mathrm{CH}_{3}\right)$. Please see Figure S4.

\subsection{3-[1-(2,6-Dihydroxy-pyrimidin-4-yl)-5-methyl-2,5-dihydro-1H-tetrazol-5-yl]-4-hydroxy-} chromen-2-one

5e: $\mathrm{mp}=223-225{ }^{\circ} \mathrm{C}, \mathrm{R}=45 \%$, IR ( $\mathrm{KBr}$ disc, $\left.\mathrm{cm}^{-1}\right)$ : 3450.05, 3420-3100, 3079.55, 2947.48, 1727.86, 1665.82, 1660.24, 1054.26, 986.29, 761.25. ${ }^{1} \mathrm{H}-\mathrm{NMR} ;(\delta, \mathrm{ppm}) 7.6-7.4(\mathrm{~m}$, $2 \mathrm{H}, \mathrm{Ar}), 7.2-7.0(\mathrm{~m}, 2 \mathrm{H}, \mathrm{Ar}), 5.2(\mathrm{~s}, 2 \mathrm{H}),, 4.5(\mathrm{~s}, 1 \mathrm{H}), 3.5(\mathrm{~s}, 1 \mathrm{H}), 2.2(\mathrm{~s}, 1 \mathrm{H}), 1.4\left(\mathrm{~s}, 3 \mathrm{H}, \mathrm{CH}_{3}\right)$. ${ }^{13} \mathrm{C}-\mathrm{NMR} ;(\delta, \mathrm{ppm})$ 172.6, 165.5, 163.4 (C=O), 161.0 (C-N, Pyr.), 151.2, 129.2, 128.8, 127.3, 126.2, 125.5, 122.6, 121.2, 102,4, 78.8 (C-Tetraz.), $21.3\left(\mathrm{CH}_{3}\right)$. Please see Figure S5. 
Antibacterial activity is screened by measuring the zones of inhibition around the standard discs saturated with solutions of the products in N,N-DMF with concentrations of $2 \mathrm{mg} / \mathrm{mL}, 4 \mathrm{mg} / \mathrm{mL}$ and $6 \mathrm{mg} / \mathrm{mL}$, incubation at $37^{\circ} \mathrm{C}$ for $48 \mathrm{~h}$.

\section{Conclusions}

Novel-substituted-[(pyridinyl-and-[(pyrimidin-2-ylimino)-ethyl]-4-hydroxy-chromen2-ones 4(a-e) and respective 3-substituted pyridin-2-yl and pyrimidin-2-yl-5-methyl-2,5dihydro-1H-tetrazol-5-yl]-4-hydroxy-chromen-2-one 5(a-e) are synthesized in the moderate and high yield. The synthesis was done stepwise with different reactants in different condition. Synthesis is carried off by refluxing the reaction mixture for a given period. Synthesized compounds were characterized on the basis of their spectrometric data. The impact of polar substituents in antibacterial activity was significant, so compounds with chlorine and hydroxyl substituents showed expressed activity against $S$. aureus, E. coli, and Klebsiella bacteria. Antibacterial activity is shown to be proportional to the concentration of these compounds. The compounds $4 \mathrm{e}$ and $5 \mathrm{e}$ have shown significant activity at E. coli. The compounds $\mathbf{5 b}$ and $\mathbf{5 e}$ showed very good antibacterial activity at Klebsiella, whereas compound $4 \mathrm{~b}$ has shown good activity at $S$. aureus.

Supplementary Materials: The following are available online, all synthesized compounds are characterization by spectral methods, IR and NMR. Graphical presentation of inhibition zone diameter $(\mathrm{mm})$ against $S$. aureus. Graphical presentation of inhibition zone diameter (mm) against E. coli. Graphical presentation of inhibition zone diameter $(\mathrm{mm})$ against Klebsiella. Melting points are shown melting points for synthesized compounds 4(a-e) and 5(a-e). Figure S1. 2. 3-Acetyl-4-hydroxychromen-2-one. Figure S2. 5a. 3-[1-(5-Chloro-pyridin-2-yl)-5-methyl-2,5-dihydro-1H-tetrazol-5-yl]-4hydroxy-chromen-2-one. Figure S3. 5b. 3-[1-(3,5-Dichloro-pyridin-2-yl)-5-methyl-2,5-dihydro-1Htetrazol-5-yl]-4-hydroxy-chromen-2-one. Figure S4. 5d. 3-[1-(3-Benzyloxy-pyridin-2-yl)-5-methyl-2,5dihydro-1H-tetrazol-5-yl]-4-hydroxy-chromen-2-one. Figure S5. 5e. 3-[1-(2,6-Dihydroxy-pyrimidin-4yl)-5-methyl-2,5-dihydro-1H-tetrazol-5-yl]-4-hydroxy-chromen-2-one.

Author Contributions: Conceptualization, R.H., H.I. and V.T.; Methodology, R.H., H.I. and G.M.-O.; Investigation, R.H., H.I., V.T., M.P.-Z., A.B. and G.M.-O.; Writing-Original Draft, R.H., H.I. and V.T.; Writing-Review \& Editing, R.H., H.I., V.T. and M.P.-Z.; Resources, R.H., H.I. and A.B.; Supervision, R.H. All authors have read and agreed to the published version of the manuscript.

Funding: This research received no external funding.

Institutional Review Board Statement: Not applicable.

Informed Consent Statement: Not applicable.

Data Availability Statement: Not applicable.

Conflicts of Interest: The authors declare no conflict of interest.

Sample Availability: Samples of the compounds 2, 4(a-d), 4e, 5(a-d) and 5e are available from the authors.

\section{References}

1. Stefanachi, A.; Leonetti, F.; Pisani, L.; Catto, M.; Carotti, A. Coumarin: A Natural, Privileged and Versatile Scaffold for Bioactive Compounds. Molecules 2018, 23, 250. [CrossRef] [PubMed]

2. Jameel, E.; Umar, T.; Kumar, J.; Hoda, N. Coumarin: A Privileged Scaffold for the Design and Development of Antineurodegenerative Agents. Chem. Biol. Drug Des. 2016, 87, 21-38. [CrossRef] [PubMed]

3. Musa, M.; Cooperwood, J.; Khan, M.O. A Review of Coumarin Derivatives in Pharmacotherapy of Breast Cancer. Curr. Med. Chem. 2008, 15, 2664-2679. [CrossRef]

4. Marcu, M.G.; Schulte, T.W.; Neckers, L. Novobiocin and Related Coumarins and Depletion of Heat Shock Protein 90-Dependent Signaling Proteins. JNCI J. Natl. Cancer Inst. 2000, 92, 242-248. [CrossRef] [PubMed]

5. Khan, M.S.; Agrawal, R.; Ubaidullah, M.; Hassan, M.I.; Tarannum, N. Design, Synthesis and Validation of Anti-Microbial Coumarin Derivatives: An Efficient Green Approach. Heliyon 2019, 5, e2615. [CrossRef] [PubMed]

6. Kushwaha, K.; Kaushik, N.; Lata; Jain, S.C. Design and Synthesis of Novel 2H-Chromen-2-One Derivatives Bearing 1,2,3-Triazole Moiety as Lead Antimicrobials. Bioorg. Med. Chem. Lett. 2014, 24, 1795-1801. [CrossRef] 
7. Prusty, J.S.; Kumar, A. Coumarins: Antifungal Effectiveness and Future Therapeutic Scope. Mol. Divers. 2020, $24,1367-1383$. [CrossRef]

8. Guerra, F.Q.S.; Araújo, R.S.A.; Sousa, J.P.; Silva, V.A.; Pereira, F.O.; Mendonça-Junior, F.J.B.; Barbosa-Filho, J.M.; Pereira, J.A.; Lima, E.O. A New Coumarin Derivative, 4-Acetatecoumarin, with Antifungal Activity and Association Study against Aspergillus spp. Braz. J. Microbiol. 2018, 49, 407-413. [CrossRef]

9. Patel, K.; Karthikeyan, C.; Hari Narayana Moorthy, N.S.; Deora, G.S.; Solomon, V.R.; Lee, H.; Trivedi, P. Design, Synthesis and Biological Evaluation of Some Novel 3-Cinnamoyl-4-Hydroxy-2H-Chromen-2-Ones as Antimalarial Agents. Med. Chem. Res. 2012, 21, 1780-1784. [CrossRef]

10. Salem, M.; Marzouk, M.; El-Kazak, A. Synthesis and Characterization of Some New Coumarins with in Vitro Antitumor and Antioxidant Activity and High Protective Effects against DNA Damage. Molecules 2016, 21, 249. [CrossRef]

11. Kenchappa, R.; Bodke, Y.D.; Chandrashekar, A.; Aruna Sindhe, M.; Peethambar, S.K. Synthesis of Coumarin Derivatives Containing Pyrazole and Indenone Rings as Potent Antioxidant and Antihyperglycemic Agents. Arab. J. Chem. 2017, 10, S3895-S3906. [CrossRef]

12. Mohareb, R.; MegallyAbdo, N. Uses of 3-(2-Bromoacetyl)-2H-Chromen-2-One in the Synthesis of Heterocyclic Compounds Incorporating Coumarin: Synthesis, Characterization and Cytotoxicity. Molecules 2015, 20, 11535-11553. [CrossRef]

13. Liu, C.-F.; Shen, Q.-K.; Li, J.-J.; Tian, Y.-S.; Quan, Z. Synthesis and Biological Evaluation of Novel 7-Hydroxy-4-Phenylchromen2-One-Linked to Triazole Moieties as Potent Cytotoxic Agents. J. Enzym. Inhib. Med. Chem. 2017, 32, 1111-1119. [CrossRef] [PubMed]

14. Patel, P.; Patel, T.; Baxi, S.; Acharya, H.; Tripathi, C. Antitubercular Effect of 8-[(4-Chloro Phenyl) Sulfonyl]-7-Hydroxy-4-Methyl2H-Chromen-2-One in Guinea Pigs. J. Pharmacol. Pharmacother. 2011, 2, 253-260. [CrossRef]

15. O'Reilly, R.A.; Aggeler, P.M.; Leong, L.S. STUDIES ON THE COUMARIN ANTICOAGULANT DRUGS: THE PHARMACODYNAMICS OF WARFARIN IN MAN*. J. Clin. Invest. 1963, 42, 1542-1551. [CrossRef]

16. Olmedo, D.; Sancho, R.; Bedoya, L.M.; López-Pérez, J.L.; del Olmo, E.; Muñoz, E.; Alcamí, J.; Gupta, M.P.; San Feliciano, A. 3-Phenylcoumarins as Inhibitors of HIV-1 Replication. Molecules 2012, 17, 9245-9257. [CrossRef]

17. Bhavsar, D.; Trivedi, J.; Parekh, S.; Savant, M.; Thakrar, S.; Bavishi, A.; Radadiya, A.; Vala, H.; Lunagariya, J.; Parmar, M.; et al. Synthesis and in Vitro Anti-HIV Activity of N-1,3-Benzo[d]Thiazol-2-Yl-2-(2-Oxo-2H-Chromen-4-Yl)Acetamide Derivatives Using MTT Method. Bioorg. Med. Chem. Lett. 2011, 21, 3443-3446. [CrossRef]

18. Domitrović, R.; Potočnjak, I. A Comprehensive Overview of Hepatoprotective Natural Compounds: Mechanism of Action and Clinical Perspectives. Arch. Toxicol. 2016, 90, 39-79. [CrossRef]

19. Soni, R.; Durgapal, S.D.; Soman, S.S.; Georrge, J.J. Design, Synthesis and Anti-Diabetic Activity of Chromen-2-One Derivatives. Arab. J. Chem. 2019, 12, 701-708. [CrossRef]

20. Servet Altay, A.; Leonetti, F.; Pisani, L.; Catto, M.; Carotti, A. Prolonged Coagulopathy Related to Coumarin Rodenticide in a Young Patient: Superwarfarin Poisoning. Cardiovasc. J. Afr. 2012, 23, 9-11. [CrossRef]

21. Amin, K.M.; Abou-Seri, S.M.; Awadallah, F.M.; Eissa, A.A.M.; Hassan, G.S.; Abdulla, M.M. Synthesis and Anticancer Activity of Some 8-Substituted-7-Methoxy-2H-Chromen-2-One Derivatives toward Hepatocellular Carcinoma HepG2 Cells. Eur. J. Med. Chem. 2015, 90, 221-231. [CrossRef] [PubMed]

22. Liu, X.-H.; Li, J.; Wu, F.-R.; Song, B.-A.; Pinaki, S.B.; Shi, L. Novel 3-(2-(3-Methyl-5-Substituted-Phenyl-4,5-Dihydropyrazol-1Yl)-2-Oxoethoxy)-2-Substituted-Phenyl-4H-Chromen-4-One: Synthesis and Anticancer Activity. Med. Chem. 2011, 7, 605-610. [CrossRef] [PubMed]

23. Cai, W.; Liu, W.; Xie, Y.; Wu, J.; Liu, Y.; Liu, C.; Xu, W.; Tang, L.; Wang, J.; Zhao, G. Design, Synthesis and Biological Activity of Tetrazole-Bearing Uric Acid Transporter 1 Inhibitors. Chem. Res. Chin. Univ. 2017, 33, 49-60. [CrossRef]

24. Vellalacheruvu, R.; Leela R, S.; Lk, R. Novel Route for Synthesis of Antihypertensive Activity of Tetrazole Analogues as a Carbamate and Urea Derivatives. Med. Chem. 2017, 7, 239-246. [CrossRef]

25. Rajasekaran, A.; Thampi, P.P. Synthesis and Analgesic Evaluation of Some 5-[ $\beta$-(10-Phenothiazinyl)Ethyl]-1-(Acyl)-1,2,3,4Tetrazoles. Eur. J. Med. Chem. 2004, 39, 273-279. [CrossRef]

26. Lamie, P.F.; Philoppes, J.N.; Azouz, A.A.; Safwat, N.M. Novel Tetrazole and Cyanamide Derivatives as Inhibitors of Cyclooxygenase-2 Enzyme: Design, Synthesis, Anti-Inflammatory Evaluation, Ulcerogenic Liability and Docking Study. J. Enzym. Inhib. Med. Chem. 2017, 32, 805-820. [CrossRef]

27. Hoti, R.; Nura-Lama, A.; Mulliqi-Osmani, G.; Troni, N.; Gashi, F.; Ismaili, H.; Thaçi, V. Synthesis of 4-Triazolylamino- and 4-Benzothiazolylamino-3- Nitro-2H-[1]-Benzopyran-2-Ones and Their Antimicrobial Activity. Orbital Electron. J. Chem. 2014, 6, 184-190.

28. Hoti, R.; Ismaili, H.; Vehapi, I.; Troni, N.; Mulliqi-Osmani, G.; Thaçi, V. Synthesis of new [(3-nitro-2-oxo-2H- chromen-4-ylamino)phenyl]-phenyl- triazolidin-4-ones and their antibacterial activity. Chem. Bulg. J. Sci. Educ. 2017, 26, $262-274$.

29. Hoti, R.; Troni, N.; Ismaili, H.; Pllana, M.; Pacarizi, M.; Thaçi, V.; Mulliqi-Osmani, G. Synthesis of new 3-[(chromen-3-YL)ethylideneamino]-phenyl]-thiazolidin-4- ones and their antibacterial activity. Chem. Bulg. J. Sci. Educ. 2018, 27, 109-119.

30. Abdou, M.M. 3-Acetyl-4-Hydroxycoumarin: Synthesis, Reactions and Applications. Arab. J. Chem. 2017, 10, 3664-3675. [CrossRef]

31. Bauer, A.W.; Kirby, W.M.M.; Sherris, J.C.; Turck, M. Antibiotic Susceptibility Testing by a Standardized Single Disk Method. Am. J. Clin. Pathol. 1966, 45, 493-496. [CrossRef] [PubMed] 
32. Hudzicki, J. Kirby-Bauer Disk Diffusion Susceptibility Test Protocol; ASM MicrobeLibrary; American Society for Microbiology: New York, NY, USA, 2009.

33. Abdelmajeid, A.; Ali, a.A.; Ashour, M. Synthesis and Evaluation of in Vitro Biological Activity of New Series of Quinazolinone and Benzoxazinone Derivatives. Egypt. J. Chem. 2021, 64, 2653-2661. [CrossRef]

34. Saleh, M.; Ayoub, A.; Hammady, A. Synthesis Biological Studies of Some New Heterocyclic Compound Derived from 2-Chloro-3Formyl Quinoline and 4-(Benzyl Sulfonyl) Acetophenone. Egypt. J. Chem. 2020, 63, 4769-4776. [CrossRef] 